Journal of Social Sciences 6 (2): 252-255, 2010

ISSN 1549-3652

(C) 2010 Science Publications

\title{
Learning Outcomes of Project-Based and Inquiry-Based Learning Activities
}

\author{
${ }^{1}$ Mookdaporn Panasan and ${ }^{2}$ Prasart Nuangchalerm \\ ${ }^{1}$ Muangnakhonratchasima School, Amphoe Muang, Nakhonratchasima 30000 Thailand \\ ${ }^{2}$ Department of Curriculum and Instruction, Faculty of Education, Mahasarakham University, \\ Mahasarakham 44000 Thailand
}

\begin{abstract}
Problem statement: Organization of science learning activities is necessary to rely on various methods of organization of learning and to be appropriate to learners. Organization of projectbased learning activities and inquiry-based learning activities are teaching methods which can help students understand scientific knowledge. It would be more efficient. This study aimed to compare learning achievement, science process skills and analytical thinking of fifth grade students who learned by using organization of project-based and inquiry-based learning activities. Approach: The sample used in the study consisted of 88 fifth grade students, 2 selected classrooms at Muang Nakhon Ratchasima School, under the Office of Nakhon Ratchasima Educational Service Area Zone 1 in the first semester of the academic year 2008, obtained cluster random sampling technique. Students were divided into 2 groups, 44 students each. The research instruments used in the study were lesson plans for organization of project-based and inquiry-based learning activities, 8 plans each; a 30-item 4choice science learning achievement test with discriminating powers ranging $0.28-0.46$ and a reliability of 0.86 ; a 20-item 4-choice science process skill test with difficulties (P) ranging 0.36-0.68, discriminating powers ranging $0.38-0.72$ and a reliability of 0.82 and a 20 -item 4-choice analytical thinking test with difficulties $(\mathrm{P})$ ranging $0.44-0.67$, discriminating powers ranging $0.32-0.81$ and a reliability 0.76 . Hotelling $\mathrm{T}^{2}$ was employed for testing hypotheses. Results: The plans for organization of project-based and inquiry-based learning activities in the science learning had efficiencies $89.05 / 78.79$ of project-based learning and 87.58/78.64 of inquiry-based learning in respectively. The plans for organization of project-based and inquiry-based learning activities had effectiveness indices 0.6774 of project-based learning and 0.6781 of inquiry-based learning in respectively. Students who learned using the plans for organization of project-based learning activities and those who learned using the plans for organization of inquiry-based learning activities did not have different learning achievement, science process skills and analytical thinking ( $p>0.05$ ). Conclusion: In conclusion, the plans for organization of project-based and inquiry-based learning activities were appropriately efficient and effective. The students in 2 groups did not show different learning achievement, science process skills and analytical thinking. Therefore, science teachers could implement both of these teaching methods in organization of activities as appropriate for learners to achieve in the future.
\end{abstract}

Key words: Project-based learning, inquiry-based learning, learning achievement, analytical thinking, science process skills, science teaching, science education, learning model

\section{INTRODUCTION}

In the context of changing world, science and technology play its important roles in all level of community. School need to develop students in terms of scientific knowledge and promote them make thinking critically, doing empirically based on nature of science, scientific literacy (Nuangchalerm, 2010). The pedagogical aspects need to have inquiring mind in science and make them to meet both science in appropriate ways. Also, instructional strategies in school science should allow students meet the goals of science education. It is to enable students to observe their natural environment and to develop skills required to understand and explain both themselves and their environment (Marx et al., 2004).

Students need to include some the key aspects of inquiry-based classroom, new knowledge is incorporated through sensory stimuli by incorporating students' current and prior understandings (Kirschner et al., 2006).

Corresponding Author: Prasart Nuangchalerm, Department of Curriculum and Instruction, Faculty of Education, Mahasarakham University, Mahasarakham 4400 Thailand 
Students will be engaged and express their feeling how learning environment will be incorporated. They are continuously building and rebuilding understanding, need to reflect on their knowledge and experiences as well. Inquiry-based learning is a practical method for establishing the connections between prior knowledge and scientific descriptions of natural world. They should be provided with opportunities to appreciate and understand various forms of scientific inquiry (Nuangchalerm and Thammasena, 2009).

Inquiry-based learning can be referred to diverse ways in which scientists study the natural world and propose explanations based on evidence derived from their study. It included the activities of students in which the develop knowledge and understanding of scientific ideas, as well as an understanding of how scientists study the natural world (National Research Council, 1996). The inquiry teaching challenges science learning to develop new content knowledge, pedagogical techniques, approaches to assessment and classroom management (Krajcik et al., 1998). It mean that inquiry-based learning can lead students open their windows of opportunities to explore and understand about natural world by themselves.

Project-based learning is a model that organizes learning around projects. It is definitely based on challenging questions or problems that involve students in design, problem-solving, decision making, or investigative activities; give students the opportunity to learn relatively (Jones et al., 1997; Marx et al., 1994). Students have a chance to solve interdisciplinary problems by themselves and also they can response activities outside the school environment (Holubova, 2008). In reaching instructional goals, students' perceptions of achievement, understanding of learning, studying habits and interactions with others in the teaching and learning environment are some of the determining factors.

This study aimed to compare learning achievement, science process skills and analytical thinking of fifth grade students who learned by using organization of project-based and inquiry-based learning activities. The results of this study can help students meet nature of science and stimulate them to have habit of mind in science.

Objective: To compare learning achievement, science process skills and analytical thinking of fifth grade students organized between project-based instruction and inquiry-based instruction.

Hypothesis: Learning achievement, science process skills and analytical thinking of fifth grade students organized between project-based instruction and inquiry-based instruction are difference.

\section{MATERIALS AND METHODS}

Populations and sample: The populations of this research comprised of nine classrooms, 396 of 5th grade students attending in the first semester, academic year 2009 of Koratpittayakom School.

The samples of the research were 88 of 5 th grade students attending in the first semester, academic year 2009 of Muangnakhonratchasima School by cluster random sampling. Forty four students were from 1 classroom was project-based instruction and another classroom with forty four students was inquiry-based instruction.

Research tools: There were four kinds of the research tools used for this research as follows:

- There were 2 kinds of lesson plans, including eight lesson plans of project-based instruction and of inquiry-based instruction. The researchers spent $16 \mathrm{~h}$ to finish these plans

- Achievement test with thirty items of four multiple choices, its discriminating powers ranging was between 0.28 and 0.46 and a reliability was 0.86

- Twenty items of four multiple choices test on analytical thinking, its difficulty index was between 0.44 and 0.67 , its discriminating power was between 0.32 and 0.81 and the test reliability was 0.76

- Twenty items of four multiple choices test on science process skills, its difficulty index was between 0.36 and 0.68 , its discriminating power was between 0.38 and 0.72 and the test reliability was 0.82

Data collection and analysis: This research conducted pre-test with two groups of experiment by achievement test, analytical thinking and science process skills. Then, two instructional practices were implemented and followed by Post-test. Data were analyzed were mean, percentage and standard deviation. The research hypothesis was approved by Hotelling's $\mathrm{T}^{2}$.

\section{RESULTS}

Effective teaching criterion: Performance score of activities were measured during project-based and inquiry-based classroom, data were collected. The plans for organization of project-based and inquiry-based learning activities in the science learning had efficiencies 89.05/78.79 of project-based learning and $87.58 / 78.64$ of inquiry-based learning in respectively (Table 1 and 2). 
J. Social Sci., 6 (2): 252-255, 2010

Table 1: Effective teaching criterion of project-based instruction

\begin{tabular}{lrrr}
\hline & Pretest & Performance score & Posttest \\
\hline Total & 452.00 & 4702.00 & 1040.00 \\
Mean & 10.27 & 106.86 & 23.64 \\
SD & 1.70 & 6.03 & 2.67 \\
Percentage & 34.24 & 89.05 & 78.79 \\
\hline
\end{tabular}

Table 2: Effective teaching criterion of inquiry-based instruction

\begin{tabular}{lrrr}
\hline & Pretest & Performance score & Posttest \\
\hline Total & 444.00 & 4624.00 & 1038.00 \\
Mean & 10.09 & 105.09 & 23.59 \\
SD & 1.52 & 6.13 & 2.46 \\
Percentage & 33.64 & 87.58 & 78.64 \\
\hline
\end{tabular}

Table 3: Effective index of project-based instruction

\begin{tabular}{ll} 
Total pretest & 425 \\
Total posttest & 1040 \\
EI & 0.6774 \\
\hline
\end{tabular}

Table 4: Effective index of inquiry-based instruction

\begin{tabular}{ll}
\hline Total pretest & 444 \\
Total posttest & 1038 \\
EI & 0.6781 \\
\hline
\end{tabular}

Effective indices: This study applies the Effectiveness Index (EI) methodology, developed to measure students' cognitive development. It can measure involves comparing the actual change in a given outcome from baseline (P1) to follow-up (P2) to potential change (100-P1). The E.I. is thus computed as follows:

$$
\mathrm{EI}=[(\mathrm{P} 2-\mathrm{P} 1) /(100-\mathrm{P} 1)] * 100
$$

The plans for organization of project-based and inquiry-based learning activities had effectiveness indices 0.6774 of project-based learning and 0.6781 of inquiry-based learning in respectively (Table 3 and 4).

Comparisons of learning achievement, science process skills and analytical thinking between project-based and inquiry-based instructions: Researchers analyzed the correlation of learning achievement, analytical thinking and moral reasoning between two teaching methods (Table 5).

Three variables- learning achievement, analytical thinking and moral reasoning were correlated different at 0.05 level of statistical significance. Then researchers employed three variables test by Hotelling's $\mathrm{T}^{2}$ (Table 6).

Learning achievement, analytical thinking and science process skills of fifth grade students learned by project-based instruction and inquiry-based instruction were not different at 0.05 level of statistical significance.
Table 5: Correlation of learning achievement, analytical thinking and moral reasoning

\begin{tabular}{lll}
\hline Correlation & Science process skills & Analytical thinking \\
\hline Learning achievement & $0.390^{*}$ & $0.614^{*}$ \\
Science process skills & - & $0.476^{*}$ \\
\hline *: Statistical significance of differences at 0.05 &
\end{tabular}

Table 6: Test of mean differences among learning achievement, analytical thinking and science process skills

\begin{tabular}{llllll}
\hline Statistical test & Value & Hypothesis df & Error df & $\mathrm{F}$ & $\mathrm{p}$ \\
\hline Pillai's trace & 0.016 & 3.00 & 84.00 & $0.450 \mathrm{a}$ & 0.718 \\
Wilks' lambda & 0.984 & 3.00 & 84.00 & $0.450 \mathrm{a}$ & 0.718 \\
Hotelling's trace & 0.016 & 3.00 & 84.00 & $0.450 \mathrm{a}$ & 0.718 \\
Roy's largest root & 0.016 & 3.00 & 84.00 & $0.450 \mathrm{a}$ & 0.718 \\
\hline
\end{tabular}

\section{DISCUSSION}

The findings of this study can be discussed that effective teaching criterion seems to study students had performance score and percent of posttest score higher than those 75/75. It means that students can build new understanding through interactions with their environment. Also, the effectiveness index showed that students can gain their knowledge and experiences of scientific conception after learned by project-based and inquiry-based instructions. It can be used and implied for science education in terms of teachers' teaching preparation.

Science teachers should understand that constructivist theory can provide meaning to teaching and learning by beginning lessons with what students know and understand. The comparisons of learning achievement, analytical thinking and science process skills of fifth grade students learned by project-based instruction and inquiry-based instruction were not different at 0.05 level of statistical significance. It means that teachers can implement project-based or inquiry-based learning activities. It helps students construct knowledge through real world problemsolving based on information gained during experimentation. Students should be provided with opportunities to appreciate and understand various forms of instructional strategies.

\section{CONCLUSION}

In conclusion, the plans for organization of projectbased and inquiry-based learning activities were appropriately efficient and effective. The students in two groups did not show different learning achievement, science process skills and analytical thinking. Therefore, science teachers could implement both of these teaching methods in organization of activities as appropriate for learners to achieve in the future. 


\section{REFERENCES}

Holubova, R., 2008. Effective teaching methods project-based learning in physics. US-China Educ. Rev., 5:

27-36. http://www.teacher.org.cn/doc/ucedu200812/ucedu 20081204.pdf

Jones, B.F., C.M. Rasmussen and M.C. Moffitt, 1997. Real-Life Problem Solving: A Collaborative Approach to Interdisciplinary Learning. American Psychological Association, Washington DC., ISBN: 1557982945.

Kirschner, P.A., J. Sweller and R.E. Clark, 2006. Why minimal guidance during instruction does not work: an analysis of the failure of constructivist, discovery, problem-based, experiential and inquiry- based teaching. Educ. Psychol., 41: 75-86. http://www.usc.edu/dept/education/cogtech/publica tions/kirschner_Sweller_Clark.pdf

Krajcik, J.S., P. Blumenfeld, R.W. Marx, K. Bass J. Fredricks and E. Soloway, 1998. Inquiry in project-based Science classrooms: Initial attempts by middle school students. J. Learn. Sci., 7: 313-350. http://www.informaworld.com/smpp/content conte $\mathrm{nt}=\mathrm{a} 785041401 \& \mathrm{db}=\mathrm{all}$
Marx, R.W., P.C. Blumenfeld, J.S. Krajcik, B. Fishman and E. Soloway, 2004. Inquiry-based science in the middle grades: Assessment of learning in urban systemic reform. J. Res. Sci. Teac., 41: 1063-1080. http://www.its-about-time.com/htmls/pbis/letuspaper.pdf

Marx, R.W., P.C. Blumenfeld, J.S. Krajcik, M. Blunk and B. Crawford et al., 1994. Enacting projectbased science: Experiences of four middle grade teachers. Elem. Sch. J., 94: 517-538. http://www.jstor.org/pss/1001840

National Research Council, 1996. National Science Education Standards. National Academy Press, Washington DC., ISBN: 10: 0-309-05326-9.

Nuangchalerm, P. and B. Thammasena, 2009. Cognitive development, analytical thinking and learning satisfaction of second grade students learned through inquiry-based learning. Asian Soc. Sci., 5: 82-87. http://www.eric.ed.gov/ERICWebPortal/contentdel ivery/servlet/ERICServlet?accno=ED506511

Nuangchalerm, P., 2010. Engaging students to perceive nature of science through socioscientific issuesbased instruction. Eur. J. Soc. Sci. 13: 34-37. http://www.eric.ed.gov/ERICWebPortal/contentdel ivery/servlet/ERICServlet?accno=ED508531 